\title{
School libraries and school librarianship in Brazil
}

\author{
Bernadete Campello \\ School of Information Science, Federal University of Minas Gerais \\ Av. Presidente Antônio Carlos, 6627 \\ 31270-901 Belo Horizonte - MG \\ Brazil \\ bscampello@gmail.com
}

This paper aims to outline a summary of the situation of school libraries in Brazil and of issues that affect their development, using the methodology of textual analysis. Two points emerge from the analysis: 1) the emergence of academic research groups since the 1990s and the consequent increase in school library studies indicate that the theoretical foundation for the improvement of these institutions is being built and 2) the enactment, on May 24, 2010 of Act 12244 which enforces that each Brazilian school of basic education has a library represented a great achievement but its effectiveness remains to be proven.

Keywords: School libraries, School Librarianship, Brazil

\section{Introduction}

The first school libraries emerged in Brazil in the sixteenth century in the convents of the Jesuit priests who arrived in the country to convert the Indians and instruct the first Portuguese settlers. In the seventeenth century, other religious orders were established and its facilities housed libraries that supported the teaching role of these institutions. Although the convents have suffered a period of decline in the eighteenth century, religious orders continued to maintain schools now to meet the learning demands of the society elite: children of businessmen, intellectuals and government officials, like what happens until today. Currently, in the private education sector, in addition to religious schools, there is a range of secular educational institutions with various pedagogical orientations. Within public schools, libraries began to be created around the 1930s, when education was influenced by innovative learning methods stimulated by the movement called New School (Silva, 2011), coinciding with the creation of library schools in the country.

Nowadays, although the curriculum guidelines for basic education recommend teaching based on constructivist theories and consider the school library as a key learning resource (Brazil, 1997), many studies point to the precarious situation of school libraries.

\section{Objective and Methodology}

This paper aims to outline a summary of the situation of school libraries in Brazil and of issues that affect their development. The methodology was textual analysis made of relevant documents selected among those presenting statistical data, and critical and evaluative studies on the panorama of Brazilian school libraries.

\section{School Libraries Overview}

The latest data on basic education in Brazil were collected by the 2012 School Census of the Ministry of Education (MEC). The Census summary document reveals that there are 192,676 establishments of basic education in the country. Basic education serves students $0-17$ years. It is divided into: Preschool, which serves students 0-5 years; Fundamental School, 
students 6-14 years and High School, students 15 to 17 years. In these establishments there are $50,545,050$ students enrolled, being $8,322,219(16.5 \%)$ in private schools and $42,222,831(83.5 \%)$ in public schools. Of these, concerning school jurisdiction, the county accounts for nearly half of all enrollments $(45.9 \%)$, the equivalent of $23,224,479$ students, followed by state schools, which serve $37.0 \%$ of the total of public schools $(18,721,916$ students); the federal public schools participates with $0.5 \%$, namely 276,436 students (Brazil, 2013). The Census document presents the percentage of libraries/reading rooms in fundamental and high schools, shown in Table 1.

Table 1: Students in Fundamental and High Schools with Access to a Library/Reading Room

\begin{tabular}{|c|c|c|c|c|c|}
\hline $\begin{array}{c}\text { Education } \\
\text { level }\end{array}$ & $\begin{array}{c}\text { School } \\
\text { jurisdiction }\end{array}$ & $\begin{array}{c}\text { Number } \\
\text { of } \\
\text { schools }\end{array}$ & $\begin{array}{c}\text { \% of schools } \\
\text { with library/ } \\
\text { reading room }\end{array}$ & $\begin{array}{c}\text { Number of } \\
\text { students }\end{array}$ & $\begin{array}{c}\% \text { of students } \\
\text { with access to } \\
\text { library/reading } \\
\text { room in the } \\
\text { school }\end{array}$ \\
\hline $\begin{array}{c}\text { Fundamental } \\
\text { school }\end{array}$ & Public & 122,716 & $\mathbf{4 2 . 2} \%$ & $25,431,566$ & $\mathbf{7 5 . 1 \%}$ \\
\cline { 2 - 6 } & Private & 21,989 & $\mathbf{8 4 . 4 \%}$ & $4,270,932$ & $\mathbf{9 0 . 9 \%}$ \\
\cline { 2 - 6 } High school & Public & 19,279 & $\mathbf{8 7 . 4 \%}$ & $7,310,689$ & $\mathbf{9 2 . 4 \%}$ \\
\cline { 2 - 6 } & Private & 7,885 & $\mathbf{9 3 . 4 \%}$ & $1,066,163$ & $\mathbf{9 4 . 5 \%}$ \\
\hline
\end{tabular}

Source: Ministry of Education, National Institute for Educational Studies. Census of Basic Education: 2012 - Technical Summary (Brazil, 2013).

The above numbers indicate that the library is not available for many students from six to fourteen years old, in a stage of education in which access and use of books and other informational materials will have a strong influence on their literacy. The library is not available mainly for students with more difficult access to these resources outside of school, that is, those who attend public school. The numbers improve in private schools and also at the high school level.

Theoretically the school library has been for a long time recognized as essential to the learning process. "Teaching and library are not mutually exclusive, they complete each other; without a library a school is an imperfect instrument" said the Brazilian educator Lourenço Filho in the forties (Lourenço Filho, 1946).

The discourse of sectors involved with education in the country is lavish in reinforcing the importance of the school library. Several documents of public education policies emphasize the value of the school library in improving reading (Brazil, 1997; Paiva \& Berenblum, 2009). The library profession also recognizes the importance of a good library at school and has been striving continuously to show their value in improving education (Campello, 2003).

\section{School Libraries Surveys}

Since 1979, at least eighteen surveys raised data on school libraries, confirming their fragile condition and showing concern and, in some cases, outrage, about their situation. The surveys analyzed sets of libraries in specific areas, with the clear intention of exposing precarious situations and to raise awareness of needed changes, thus focusing primarily in the libraries shortcomings (Campello et al., 2012).

One can then say that the situation of school libraries in the country has not yet been resolved. The presence of good libraries is limited to a few schools (usually in the private sector and located in larger cities, especially the capitals of states in the Southeast and South regions). 
In 2009, the Ministry of Education, with the participation of the Organization of IberoAmerican States, conducted a large study that resulted in the document Assessment of School Libraries in Brazil (MEC, 2011), that concluded that books distribution policies, which were the main instruments for improving reading levels of students in Brazil, had little influence on improving public schools libraries.

The study confirmed some of the results of previous surveys, as described below.

- The foregoing bond between the school library and the school pedagogical project

The library exists as an appendix, according to the study often as a "nuisance", occupying a space that could be allocated to classrooms (MEC, 2011). In fact, it often happens that the library be disassembled to transform its space in a classroom. There is little school community participation in planning library activities, hindering its integration into the curriculum. The classroom teacher understands the importance of the library but does not use it as a space for empowerment of his/her work. The library staff seems quite aloof from school activities as a whole, not interacting with the pedagogical staff.

- The lack of skilled professionals

Those responsible for the library are mostly teachers, which at first sight might be considered a plus point given the possibility of counting with them to develop educational projects in the library. However, there are several negative aspects: these teachers are usually retrofitted without specific training for the role, they usually split time in the library with another function at school. It is common that these teachers assume the classroom teacher function in case of teacher shortage, getting the library closed at such times.

The number of graduate librarians in school libraries is low: in the Ministry of Education study it ranged from $34.8 \%$ (in the State of Santa Catarina) to none (in the State of Acre). Other studies (Campello et al., 2012) showed that there is variation in these percentages, depending on the region and libraries jurisdiction (whether public or private schools). The absence of a skilled professional to take responsibility for the library brings several consequences, from deactivation of space, to limiting opening hours, and precariousness of the services offered.

\section{- The precariousness of physical space}

Although most schools have a specific space for what they call the school library, there are several problems with this space. They are confined spaces, adapted from conventional classrooms, most of them with $538.2 \mathrm{ft}^{2}$. Some share the space with other activities, eg, photocopier, computer room, school office. The lack of space is a limiting factor, precluding carrying out library activities with a whole class or with larger groups of students.

\section{- The collections}

The collections consist primarily of material for students, received through donations from the National School Library Program (Programa Nacional Biblioteca na Escola - PNBE) which, despite its broad denomination, is an annual project which aims to provide public schools with library materials selected by public institutions of higher education, according to guidelines and criteria established by the Ministry of Education. Other donations sources are government agencies or either campaigns organized by the school. Many collections are formed predominantly of textbooks and, in some cases the library is used as storage and distribution space of these books. Few libraries have financial resources specifically for the acquisition of library material. The collections are diverse and include books, newspapers, magazines, audiovisual resources, games, maps. It seems that only now library collections 
are beginning to show an increase in number and quality resulting from the dispatch since 1997 of PNBE material. However, these rich and varied materials are not used properly, the books received usually remain in their original packaging and/or stored in locked cabinets, unavailable for use.

- The poverty of the services offered

The services offered in the library are commonly home loan and on-site use a situation coherent with the lack of skilled personnel: these are routine services, which do not require planning or proactive action and do not demand any degree of interaction with teachers. It also confirms the user's conception of the library: a collection of books. There are no systematic and sustained programs for teaching information skills, although the concept of information literacy is being discussed in academic LIS environments.

- Inadequate technical treatment of the collections

Techniques for collection organization do not generally follow bibliographic standards. Some libraries use a color code to identify different subjects. Computerized systems are rarely used in public school libraries, although currently some library networks begin to acquire software for collection organization. The lack of poor technical organization brings consequences: the library remains a particular field of the employee working there. It is only he/she who knows the entire collection, who knows how to find each book or who took a particular book for loan, among other things.

\section{- Possibilities for internet access}

There are no consistent data about internet access in school libraries. Some studies indicate that equipment and technologies start, tenuously, to be present in public school libraries. The 2012 Educational Census (Brazil, 2013) indicated the existence of internet access in $44.8 \%$ of the 122,716 public schools in the fundamental level. This number increases significantly in private schools and in high schools, repeating the same trend observed with respect to the existence of the library/reading room.

Currently there are three government programs at the federal level aimed at expanding access to the Internet in schools:

- National Program of Educational Technology (PROINFO), created in 1997, which aims to promote pedagogical use of computer and telecommunications technologies in public fundamental and high schools by implementing technological environments equipped with computers and digital resources in schools. (http://portal.mec.gov.br/index.php?ltemid=462)

- Broadband Program in Schools (PNBLE), created in 2008, with the purpose of connecting all urban public schools to the internet, enabling the installation of network infrastructure and ensuring the maintenance of services without charge until 2025.

(http://www.mc.gov.br/acoes-e-programas/programa-nacional-de-banda-larga-pnbl)

- One Laptop per Child (PROUCA) started in 2010, aiming to promote digital inclusion by distributing one laptop equipped for wireless network and Internet connection for each student and teacher in public schools of basic education. (http://www.uca.gov.br/institucional/)

The trend thus is the increasing access to equipment, although it is not clear how school libraries will use technological resources to expand their collections and enhance their services. 
This analysis of the main problems affecting Brazilian school libraries can be closed with the observation made in the document Assessment of School Libraries in Brazil:

"... in the historical process of the construction of the library, there is the coexistence of a sophisticated world accelerated by technological innovations and another who has not succeeded in appropriating the writing and reading code, represented by the absence of equipment and technology in the libraries, the book remaining the main learning material..." (MEC, 2011).

In the next part of this paper the following aspects related to school libraries will be addressed: librarians' education, research, events, publications and professional associations.

\section{Librarians' Education}

Formal education of librarians in Brazil began in 1915 with the creation of a librarianship program at the National Library in Rio de Janeiro, which was intended to train specialists to work in the Library itself. The program had a humanist bias, with strong influence of the École de Chartes of the French national library. The second program was created in São Paulo in 1929 in the Mackenzie College, under the coordination of the American librarian Dorothy Muriel Gedds, and inspired by the American model, with emphasis on technical aspects of the profession. In 1936, another program was created by the Department of Culture of the city of São Paulo and in the 1940s and 1950s seven new programs were created (Valentim, 2002).

In 1962, librarianship gained the status of a high education profession; existing courses were assimilated by universities and others were created and there was the standardization of curriculum disciplines, through the first Minimum Curriculum established by the Ministry of Education. In 1982, the Curriculum was updated with the establishment of the second Minimum Curriculum, which divided subjects into three groups: general basic subjects, professional technical subjects and instrumental courses. In the 1990s, with the modernization process of Brazilian higher education, the Minimum Curriculum was replaced by Curriculum Guidelines, which provided more freedom to the universities to set their curricula, giving faculties the possibility of organizing their pedagogical projects according to their interests. Curriculum flexibility, a current trend, allows students to compose their academic trajectory within limits defined by the faculties (Valentim, 2002).

Currently there are 39 undergraduate programs that make up the degree in library science: 25 in public universities and thirteen in private institutions. It is observed from Table 2 a large concentration of courses in the Southeast Region, which includes the more developed states.

Table 2: Number of Library Science Programs by Region

\begin{tabular}{|c|c|c|c|}
\hline \multirow{2}{*}{ Regions } & \multicolumn{2}{|c|}{ Number of programs } & \multirow{2}{*}{ Total } \\
\cline { 2 - 3 } & Public & Private & \\
\hline North & 2 & 0 & 2 \\
\hline Northeast & 8 & 0 & 8 \\
\hline Midwest & 3 & 2 & 5 \\
\hline Southeast & 7 & 10 & 17 \\
\hline South & 6 & 1 & 7 \\
\hline TOTAL & 26 & 13 & 39 \\
\hline
\end{tabular}

Source: http://www.crb6.org.br/carreira.php 
The training of four years and a minimum of 2,500 hours includes time for internships and supplementary activities. It is a generalist training, preparing the librarian to work in any type of library.

\section{School Librarians' Education}

Diversification in librarians' training, that could result in a more appropriate professional profile for different types of libraries, could happen in undergraduate programs through elective courses, internships and supplementary academic activities. But the fact is that most programs do not offer elective courses in a regular basis. Most students often fulfill their internship projects in academic and special libraries, which is where are more and better employment opportunities. Thus, specific training of school librarians does not occur during under their undergraduate courses. There is, however, a desire consistently expressed by the library community that library schools include in their curricula courses related to school libraries in order to provide opportunities for students who want to work in school libraries. But the generalist education of librarians at the undergraduate level is a practice that should remain. As a result, those few students who are interested in a career in school librarianship seek complementary specialization courses in education subjects, usually after they are already in the job market.

Specialized programs at the graduate level on school librarianship (some in a distance learning mode) began to be offered by LIS departments after the enactment of Act $12244 / 2010$, which requires that all schools in the country should have a library. These programs, with duration of 360 hours, however, usually do not have a regular offering, depending on the availability of candidates, which in general is not abundant. Besides they confer no formal degree in library science.

In order to increase the number of librarians, the Ministry of Education provided funds for public universities that already have a program in the classroom mode to offer undergraduate programs in librarianship in distance mode under the Open University of Brazil (UAB). Federal University of Rio de Janeiro (UFRJ) was the institution chosen for the development of educational materials and for support to the programs to be offered. At the moment the project is at the stage of preparation of teaching materials and is planned to start receiving students in 2015.

\section{Research}

Academic research in the field of library science in Brazil began in the 1970s, when graduate courses started to be created at the master level, followed in the 1990s by doctoral programs. At that time most programs that began as library science programs, had changed to information science. Even with this new denomination, most programs continued to host projects on library issues, including school library. However, the first master thesis and the first doctoral dissertation on school library were completed in schools of education in 1975 and 1992, respectively.

Since the emergence of graduate programs in library science in Brazil, some sporadic surveys revealed a small production of research on the subject of school library. A study published in 2007 (Campello et al., 2007) identified in the period 1975-2002, 39 research reports on school library, among which 35 academic dissertations and theses. More recently a study covering the period 1975-2011 (Campello et al., 2013), identified 91 studies on school library, among doctoral dissertations (07), master theses (31), journal articles (10) and conference papers (22). Of these, seventy studies were located, obtained in full text and analyzed, under the following categories: 
School library as a learning space: 11 studies

Teacher / librarian collaboration: 08 studies

Use and users studies: $\quad 13$ studies

Collection: 06 studies

Reading: $\quad 17$ studies

Research process 15 studies

The traditional involvement of the school library with reading reflects in the amount of studies of this category (17 studies). On the other hand, the concern to better understand the research process, category which ranks second in number of studies (15), shows that the area is seeking knowledge to support their educational action that extends beyond reading and incorporates issues related to information literacy. It draws attention that the last study on reading was done in 2007, while the last one on research process was done in 2011, what may be a sign of a changing focus. Another aspect that the analysis revealed was that, in performing their educational function, librarians believe they must work in collaboration with teachers (category with 8 studies), and in line with the school's goals. Use and users studies, although with a significant number of studies (13), are still stuck to the traditional approach, failing to conduct an effective dialogue with pedagogical issues, essential in the school library environment.

One of the conclusions (Campello et al., 2013) was that there was a lack of clarity in the use of the theoretical framework in the studies. Although this problem appears to be being surpassed, there are still a considerable number of studies that did not use a clear theoretical framework, representing a theoretical weakness. Another conclusion was that, following an international trend (Clyde \& Oberg 2004; Oberg, 2006; Mardis, 2009) academic knowledge about school library in Brazil is expanding, which can help to get a better understanding of the issues surrounding the topic, to sustain an evidence-based practice and encourage policy actions that lead to the improvement of school libraries in the country.

Noteworthy are the following academic groups who conduct research and other actions aimed at the school library:

- The Collaboratory for Infoeducation (Colaborl), coordinated by Prof. Ivete Pieruccini, based at the Department of Library Science and Documentation, School of Communication and Arts, University of São Paulo (USP), focuses on the relationship between school library and education, the creation and redefinition of concepts, methodologies and practices linked to notions of school library as an educational, informational and cultural device (http://www.eca.usp.br/nucleos/colabori/).

- The Research Group on School Library (GEBE), coordinated by Prof. Bernadete Campello and headquartered in the School of Information Science, Federal University of Minas Gerais (UFMG) integrates researchers and students around teaching, research and outreach activities especially related to the educational role of the school library, looking for a better understanding of its potential as a learning space (http://gebe.eci.ufmg.br/).

- The Information Behaviour and Information Literacy Research Group, coordinated by Prof. Helen de Castro Silva Casarin, in the Department of Information Science, State University Júlio de Mesquita Filho, in the city of Marília, São Paulo focus their studies is information literacy, with an emphasis on the library and the school librarian, conducting studies on the development of strategies for teaching information skills to different groups of users (http://plsql1.cnpq.br/buscaoperacional/detalhegrupo.jsp?grupo=0330607Y5FR07H\#identific acao). 
- The Research Group on Practices and Reflections on School Library is coordinated by Prof. Cláudio Marcondes de Castro Filho, since 2010 in the Department of Education, Information and Communication, Faculty of Philosophy, Sciences and Letters of Ribeirão Preto, University of São Paulo, with in two research lines: 1) discourses in and about the school library; 2) the information professional: reflections on the school librarian

(http://dgp.cnpq.br/buscaoperacional/detalhegrupo.jsp?grupo=0067607PW6IRZ8).

\section{Conferences}

There are two general conferences in which librarians have the opportunity to present and discuss their research and practice:

- Brazilian Congress of Librarianship, Documentation and Information Science (CBBD), promoted since 1954 by the Brazilian Federation of Librarians, Information Scientists and Institutions (FEBAB), in partnership with affiliated associations, being a consolidated event on the national scene. It is a space for presentation and discussion of professional papers primarily.

- National Research Meeting on Information Science (ENANCIB) is organized since 1994 by the National Association for Research in Information Science (ANCIB), where research carried out in academic institutions are presented and discussed.

These conferences also welcome papers on school library that are then published in their proceedings. Specific events in the area of school library have occurred sporadically. Some of these were:

- Seminar School Library, Space of Pedagogical Action: the 1st and 3rd of these Seminars were organized by GEBE, in 1998 and 2004 respectively, and the papers presented have been published in proceedings that are available in the Group's website.

- International Forum of School Librarianship (FIBE) performed only twice, in 2008 and in 2011, incorporating the $4^{\text {th }}$ and $5^{\text {th }}$ Seminar School Library, Space of Pedagogical Action. FIBE, although without call for papers, had the presence of foreign lecturers and was the occasion for discussion of important questions about school libraries. However, these lectures were not published, limiting the impact of presentations and discussions.

In 2012, the Forum on Research in School Library, organized by GEBE and held in Belo Horizonte, congregated the leadership of school librarianship in the country and paved the way for the consolidation of a specific event in the area (Caldeira et al., 2012). The following year, GEBE in partnership with the representation of the International Association of School Librarianship (IASL) in Brazil and the Federal Council of Librarianship (CFB), organized the 1st Forum of School Librarianship: Research and Practice, under the 25th CBBD. The Forum brought together, and intends to continue to do so, researchers and professionals working in school libraries. There is an expectation that the partnership with CBBD ensures its permanence, in view of the fact that CBBD is a consolidated event, taking place since 1954 (Ferreira, Toledo and Ferreira, 1979).

\section{Publications}

Academic research generates theses and dissertations that are virtually disclosed in institutional repositories or digital libraries and sometimes published as articles in information science journals. 
There are about 15 journals in the field of information science listed on the ANCIB website, but only one specializing in school library (Biblioteca Escolar em Revista (http://revistas.ffclrp.usp.br/berev), a biannual publication, started in 2002 that rather welcome original research articles. Therefore, there is a lack of publications that takes the results of research to practitioners and that encourages evidence-based practice.

With regard to books, there is a slow increase in production with some commercial publishers starting to have an interest in the subject of school library. Noteworthy is the work of Autêntica Editora which has since 2000 been publishing books produced by GEBE, standing among them Portuguese translations of two Carol Kuhlthau's books: School Librarian's Grade by Grade Activities Program: a complete sequential skills plan for grades K-8 and Teaching the Library Research Process.

Conference papers on school libraries are few, considering, as above said, there are only two consolidated conferences in LIS in general, offering opportunity for the presentation of papers on school librarianship. Nowadays proceedings of the two conferences are published in digital format in the promoting institutions websites. Unfortunately the organizers of some sporadic events on school library have not bothered to record the presentations in proceedings and this opens a gap on the knowledge and actions on the subject.

Brazilian literature on school librarianship is gathered in LIBES database (Brazilian Literature in School Library) under the responsibility of GEBE and updated by UFMG School of Information Science where the Group is headquartered. The database seeks to gather the entire production on the subject of school library and currently contains about 400 references, including papers published since the 1960s, referring to the complete document when available in digital format (http://libes.eci.ufmg.br/).

\section{Associative Movement and Political Actions}

The librarian's associative movement is fragile in Brazil. Although most states rely on a library association, they are poorly active, developing sparse actions that have little impact on improving the profession or the school libraries in the country. Since 1959 FEBAB brings together eighteen of these state associations and has as its main mission to advocate and promote the development of the profession. It aims to coordinate and develop activities that promote libraries and their staff; to support the activities of its affiliated and associated professionals; to act as a documentation center for the memory of LIS in the country; to interact with international institutions in the LIS field; to stimulate the creation and development of special committees.

The FEBAB special committee on school library (Brazilian Commission on School Libraries CBBE) was created in 2013, during the 1st Forum of School Librarianship: Research and Practice with the following agenda:

- To work in collaboration with CFB to develop actions that put the school library in the public policy agendas of education in Brazil;

- to promote the 2nd Brazilian Forum of School Librarianship: Research and Practice;

- to encourage the participation of Brazilian librarians in international forums such as IASL.

Since librarianship in Brazil is a profession regulated by law (Act 4084/1962), there are agencies responsible for overseeing the practice of professional librarians. CFB is the federal agency that coordinates the fourteen Regional Councils. Since its installation in 1966, CFB has been not only performing the task of inspecting libraries, along with the Regional Councils, as well as conducting and supporting other activities related to the profession. 
With regard to school libraries CFB launched in 2008 the School Library Project: building an information network for public education (CFB, 2008) seeking to mobilize society and government leaders to the need to create school libraries in the country. One result of this action was the enactment, on May 24, 2010 of Act 12244 which enforces that each Brazilian school of basic education has a library.

The Law requires that the library collection has at least one book title for each enrolled student. The local school systems are responsible for the expansion of this collection, as well as for establishing guidelines for maintenance, preservation, organization and operation of school libraries. The law recommends that the library profession ensured by legal Acts $4084 / 1962$ and $9674 / 998$ be respected, and establishes a maximum term of ten years for its effectiveness.

Some Regional Councils have a more active share in promoting school libraries. The State of São Paulo Regional Council for instance, especially in the last two years, initiated several actions to disseminate a new concept for libraries, based on the document of the American Association of School Librarians Standards for the 21st Century Learner, which was translated into Portuguese. Also the State of Rio Grande do Sul Regional Council organizes, since 2009, the Gaucho Forum for Improvement of School and Public Libraries, which aims to encourage the creation of libraries in cities in the state countryside. Conducted in partnership with various public and private institutions, the Forum works through meetings in each chosen city, bringing together local education leaders, government officials, teachers and persons concerned about the library issues. To date about 30 meetings took place, with lectures, experience reports, workshops and short courses (Moro, 2011).

Stands out the initiative of Ecofuturo Institute in partnership with civil society organizations: in 2012 the Institute launched the campaign "I want my library" in order to inform policy makers, educational leaders, teachers and others interested in school library about legislative actions for the implementation of Act 12244/2010.

\section{School Libraries Standards}

Another action under the School Library Project: building an information network for public education (CFB, 2008) was the CFB collaboration with GEBE to set out standards for school libraries (GEBE/CFB, 2010). This initiative was based on the fact that, although the importance of the school library is recognized, there is a general lack of knowledge about the technical features that define what actually constitutes a school library. Thus, the setting of objective standards gives a starting point for the creation of libraries and establishes the basis for the compilation of statistics that can reveal the real situation of school libraries in the country.

\section{Conclusions}

The emergence of academic research groups since the 1990s and the consequent increase in school library studies indicate that the theoretical foundation for the improvement of these institutions is being built. The growing availability of documents on the subject on the web and the existence of LIBES as a consolidated and continuously updated database support the training of librarians committed and able to develop a more evidence based practice in school libraries.

The desired consolidation of a specific school library conference, with call for papers and proceedings publication, may strengthen this base, providing opportunity for discussion and dissemination of research results and best practices reports. 
Still there is a lack of more effective political action to convince government leaders to invest in the creation and improvement of libraries in schools. The low rates achieved by Brazil in educational indicators such as PISA - Program for International Student Assessment may be a factor that induces the federal government to invest in more effective programs for the development of school libraries, whereas the simple distribution of books, which favors more the editors than the students, has proved not to be working, as demonstrated by the evaluation of PNBE, which found that

[ ... ] Many libraries seemed deposits of books piled up without any criteria or organization and often bundled material in their original packaging were founded. Others were reduced to shelves, the books being kept in locked cabinets, unavailable for students or teachers use. In many libraries there were no records of books in catalogs, which implied ignorance on the part of the school community about the quantity and quality of the materials available to them (Paiva \& Berenblum, 2006, p. 58).

On the other hand, the Ministry of Education survey (MEC, 2011) found that investments by the federal government in selecting and sending collections for schools through PNBE have been a positive factor in mobilizing the local school systems in creating a "culture of attention to the school library". Upon receiving the PNBE collection the school needs to decide: where and how to store and organize it, who will take care of the collection and then mobilize action for its use. This mobilization results in local investments and forces schools to make pedagogical decisions that generate, according to the researchers', expectation of autonomy and usefulness for the school library (Brazil, 2011).

The effectiveness of Act 12244/2010 remains to be proven. Although the library community has shown to be hopeful that it will modify the situation of school libraries, it was also critical about the content of the law. Firstly, it is considered extremely limited, setting school library merely as "a collection of books, videographic material and documents in any format for consultation, research, study or reading". Issues such as collection organization and conservation and library functioning are treated superficially. Another criticism is the lack of instruments for monitoring compliance with library standards and quality indicators.

The strong point of the law is the presence of the librarian: it states that the profession should be respected in accordance with Act 4084/1962 which defines that the practice of librarianship is ensured to undergraduates in library science. Although Act 12244/2010 does not clearly define that each library should have a librarian, the number of professionals needed to minimally meet the requirement is an issue that has been raised, although the figures are not grounded in scientific studies. According to a survey released by CFB in June 2013 , there are 34,805 registered librarians in the country, but only 18,374 are active. The training takes place at a slow pace: from 2009 to 2012 the total number of graduates in librarianship was 5,319 (see Annex 1), which gives an average of 1,330 graduate librarians per year over the last four years. Considering the amount of schools in the country $(192,676)$, one can get an idea of the librarians' deficit over the next seven years, the time remaining to law enforcement. Only the State of Amazonas seems to be preparing to comply with Act $12244 / 2010$ and drafted a bill for the creation of libraries in the state, but this project just mirrors the federal law, repeating its shortcomings, and was still in progress in 2013.

A trend observed both in the public and in the private education systems is the formation of school libraries networks. Collaboration schemes with different characteristics are seeking ways to optimize these libraries such as the sharing of a librarian (who oversees several libraries), the sharing of cataloguing records, of staff training programs, or the design of collection development policies. But the contours of this trend are still not clear. 
The proceedings of a conference that occurred in 1982 (the 1st National Seminar on School Libraries) revealed participants' concerns in showing the ideal picture of school libraries in the context of education. The recommendations presented at the end of the event reflected the participants' desire that Brazilian school libraries should have quality and be recognized as a key element in learning (Anais, 1982). Over these thirty two years many things changed and one can say that there is a more solid understanding of the nature of the school library, enabled by academic research.

With regard to statistical data which could offer a better picture of the characteristics of school libraries, there is need to improve data collecting procedures, stating more precisely what constitutes a school library, differentiating simple cluster of books from real libraries. It is expected that the library standards set by GEBE and CFB (GEBE and CFB, 2010) can support the collection of consistent and realistic data. We believe that academic knowledge and quality statistics can help to sustain a political action that leads to the improvement of school libraries in Brazil.

\section{References}

Anais do $1^{\circ}$ Seminário Nacional sobre Bibliotecas Escolares (1982). Brasília: Instituto Nacional do Livro (INL), Centro Regional para el Fomento del Libro em America Latina y el Caribe (CERLALC).

Brasil. (1997). Ministério da Educação. Secretaria de Educação Fundamental. Parâmetros Curriculares Nacionais. Brasília: MEC/SEF. Retrieved January 5, 2014 from http://portal.mec.gov.br/seb/arquivos/pdf/livro02.pdf

Brasil. (2013) Ministério da Educação, Instituto Nacional de Estudos e Pesquisas Educacionais Anísio Teixeira. Censo da Educação Básica: 2012 - Resumo Técnico. Brasília, INEP. Retrieved January 5, 2014 from http://download.inep.gov.br/educacao_basica/censo_escolar/resumos_tecnicos/resumo_tecn ico_censo_educacao_basica_2012.pdf

Caldeira, P. T. et al. (2012). Anais do $1^{\circ}$ Fórum de Pesquisa em Biblioteca Escolar. Belo Horizonte: GEBE. Retrieved March 11, 2014 from http://gebe.eci.ufmg.br/images/1forum2012/anais_verso_completa.pdf

Campello, B. (2003). A função educativa da biblioteca escolar no Brasil: perspectivas para o seu aperfeiçoamento. In: Anais do $5^{\circ}$ Encontro Nacional de Pesquisa em Ciência da Informação. Belo Horizonte: ANCIB. Retrieved January 5, 2014 from http://gebe.eci.ufmg.br/downloads/ENAN054.pdf

Campello, B. et al. (2007). Literatura sobre biblioteca escolar: características de citações de teses e dissertações brasileiras. TransInformação, 19 (3), 227-236. Retrieved January 4, 2014 from

http://periodicos.puc-campinas.edu.br/seer/index.php/transinfo/article/view/547/527

Campello, B. et al. (2012). Situação das bibliotecas escolares no Brasil: o que sabemos? Biblioteca Escolar em Revista, 1 (1), 1 - 29. Retrieved January 4, 2014 from http://revistas.ffclrp.usp.br/BEREV/article/view/101

Campello, B. et al. (2013). Pesquisas sobre biblioteca escolar no Brasil: o estado da arte. Encontros Bibli: Revista Eletrônica de Biblioteconomia e Ciência da Informação, 18 (37), 123-156. Retrieved January $4, \quad 2014$ from https://periodicos.ufsc.br/index.php/eb/article/viewFile/1518-2924.2013v18n37p123/25335 
Conselho Federal de Biblioteconomia. (2008). Projeto Mobilizador. Biblioteca Escolar Construção de uma Rede de Informação para o Ensino Público. Brasília: Sistema CFB/CRBs. $\quad$ Retrieved January $4, \quad 2014$ from http://www.cfb.org.br/UserFiles/File/promobil/PROMOBILFINAL.pdf

Clyde, Laurel A. \& Oberg, Dianne. (2004). LIS Journals as a Source of Evidence for Evidence-Based Practice: The Case of School Libraries Worldwide. In: Ifla General Conference and Council, 70., 2004, Buenos Aires. Proceedings.

Ferreira, C. N. C.; Toledo, M. R. C. \& Ferreira, R. H. C. (1979). Jubileu dos Congressos de Biblioteconomia e Documentação: Temários, autores, trabalhos apresentados e recomendações. In: Anais do $10^{\circ}$ Congresso Brasileiro de Biblioteconomia e Documentação. Curitiba: Associação Bibliotecária do Paraná. v. 1, p. 51- 62.

Grupo de Estudos em Biblioteca Escolar \& Conselho Federal de Biblioteconomia. (2010). Biblioteca Escolar como Espaço de Produção do Conhecimento: Parâmetros para Bibliotecas Escolares Brasileiras. Belo Horizonte. Retrieved January 4, 2014 from http://www.cfb.org.br/MIOLO.pdf

Lourenço Filho, M. B. (1946). O ensino e a biblioteca. Rio de Janeiro: Imprensa Nacional. $1^{\text {a }}$ Conferência da Série A educação e a biblioteca, pronunciada na Biblioteca do DASP, em 05/07/1944.

Mardis, Marcia A. (2009). Introduction: A Gentle Manifesto on the Relevance and Obscurity of School Libraries in LIS Research. Library Trends, 58 (1), 1-8, Summer.

MEC/Organização dos Estados Ibero-Americanos. (2011). Avaliação das Bibliotecas Escolares no Brasil. Brasília: Fundação SM Brasil. Retrieved January 4, 2014 from http://www.oei.es/bibliobrasil.pdf

Moro, E. L. S. et al. (2011). Biblioteca escolar. presente! Porto Alegre: Editora Evangraf/CRB-10. Retrieved January 13, 2014 from http://www.bibliotecaescolarpresente.org.br/biblioteca.pdf

Oberg, Dianne. (2006). Editorial: School Libraries Worldwide as a Source of Evidence for Evidence-Based Practice, 1995-2006. School Libraries Worldwide, 12 (2), i-xii.

Paiva, J. \& Berenblum, A. (2009). Programa Nacional Biblioteca da Escola (PNBE): uma avaliação diagnóstica. Pro-Posições [online], 20(1), 173-188. Retrieved January 5, 2014 from http://www.scielo.br/pdf/pp/v20n1/v20n1a10.pdf

Silva, J. L. C. (2011). Perspectivas históricas da biblioteca escolar no Brasil e análise da lei 12.244/10. Revista ACB: Biblioteconomia em Santa Catarina, (16), 2, 489-517.

Valentim, M. L. P. et al. (2002). Formação do profissional da informação. São Paulo: Polis.

\section{Acknowledgment}

\section{FAPEMIG}

Fundação de Amparo à Pesquisa do Estado de Minas Gerais 
The presentation of this work in the $43^{\text {th }}$ Annual Conference $\& 18^{\text {th }}$ International Forum on Research in School Librarianship was made possible by a grant from FAPEMIG-Foundation for Research Support of Minas Gerais, Brazil.

\section{Biographical note}

Bernadete Campello is a full professor in the School of Information Science (http://www.eci.ufmg.br/) at the Federal University of Minas Gerais - UFMG, Brazil, where she coordinates the Research Group on School Libraries (http://gebe.eci.ufmg.br/). She has a PhD in Information Science and a Masters in Library Science from UFMG, where she does research and teaches about school library, library and learning and information literacy in basic education. She is the author of the books: School Library: Knowledge Underpinning Practice (http://grupoautentica.com.br/autentica/livros/biblioteca-escolar-conhecimentos-quesustentam-a-pratica/724), School Library: Themes for a Pedagogical Practice (http://grupoautentica.com.br/autentica/livros/a-biblioteca-escolar-temas-para-uma-praticapedagogica/34), Information Literacy: Educational Role of the School Librarian (http://grupoautentica.com.br/autentica/livros/letramento-informacional-funcao-educativa-dobibliotecario-na-escola/491). She also coordinated the work of the Portuguese translation and adaptation of Carol Kuhlthau's books School Librarian's Grade by Grade Activities Program: A Complete Seqüencial Skills Plan for Grades K-8 (http://grupoautentica.com.br/autentica/livros/como-usar-a-biblioteca-na-escola-umprograma-de-atividades-para-o-ensino-fundamental/51) and Teaching the Library Research Process (http://grupoautentica.com.br/autentica/livros/como-orientar-a-pesquisa-escolarestrategias-para-o-processo-de-aprendizagem/558). 